\title{
EXCHANGE, Anyone?
}

For some time now the library profession has been talking about the schism which seems to exist between the "real world" of the practicing librarian and information scientist and the "ivory tower" of library educators. Too often we have heard sentiments expressed that there is too much theory and not enough down-to-earth practical knowledge imparted in library schools. Isn't there a happy balance somewhere? The theory is usually put into proper perspective once a students gets on the job. We are all aware of the continuing debate on the role of library education-is it to produce a cataloger, a reference librarian, a data processing librarian, or is it primarily to create an attitude, a socialization of the individual?

Why have these different attitudes developed between the theorist and the practitioner? If library schools are, indeed, failing to educate adequately, isn't it as much the fault of the practicing librarian as of the teacher? What kind of feedback is being provided? Perhaps something can and should be done about it. It has been said often that many of the useful learning experiences in library schools are related to classes taught by practicing librarians or those recently "in the field."

Yet we have not really taken advantage of the exchange possibilities between library educators and practicing librarians. It is true that more and more library administrators are turning to library education as a second challenging and rewarding profession. One can name at least a dozen former directors of large academic libraries and several public libraries who are now on library school faculties. Does this mean that library schools are playgrounds for retiring administrators? Judging from some of the talent recently recruited into library education this is certainly not the case. Probably other talents in the profession can also contribute significantly to library education-subject specialists, rare books librarians, information scientists-granted that teaching methodology and qualification must always be considered.

At the same time many library educators are capable and anxious to reciprocate with academic libraries. A recent survey of Association of American Library Schools (AALS) indicated that faculty from at least sixteen schools would be interested in such an exchange program. 
Can we, or should we, encourage a free exchange of personnel? It could be a continuing education experience: a real chance to give input into the curricula of library schools on the one hand, and on the other, a retooling experience in the practical art with which educators have been accused of losing touch.

Granted details would need to be worked out. But surely such crossfertilization could only be healthy for our profession.

Isn't a dialogue long overdue?

Couldn't such an exchange work?

R. D. Stueart 